\title{
THE FATE OF AN OIL SPILL IN SÃO SEBASTIÃO CHANNEL: A CASE STUDY
}

\author{
Eliete Zanardi-Lamardo ${ }^{1, *}$, Marcia Caruso Bícego ${ }^{2}$ and Rolf Roland Weber ${ }^{2}$ \\ ${ }^{1}$ Universidade Federal de Pernambuco \\ Departamento de Oceanografia \\ (Av. Arquitetura, s/n, Cidade Universitária, 50670-901 Recife, PE, Brasil) \\ ${ }^{2}$ Instituto Oceanográfico da Universidade de São Paulo \\ (Praça do Oceanográfico, 191, 05508-120 São Paulo, SP, Brasil) \\ *Corresponding author: eliete.zanardi@ufpe.br
}

\begin{abstract}
A B S T R A C T
An oil pipeline ruptured in May 1994 and 2700 tons of crude oil leaked into the São Sebastião Channel, affecting several neighboring areas. A program for the monitoring of hydrocarbons in sediments, using the gas chromatography / flame ionization detector methodology, was being undertaken in the area at the time. The data obtained were compared to those of samples collected after the accident to determine the fate of the oil spilled and ascertain its contribution to the environment. The earlier results showed that hydrocarbons were introduced from two different sources: biogenic, mainly from terrestrial plants, and anthropogenic, as oil, in sewage and from shipping. The later data indicated that the site closest to the pipeline rupture had been the most affected. Following that, two stations located at the north entrance of the channel presented the highest $n$-alkane concentrations, suggesting that the northeasterly wind-driven currents had carried the oil northward. Seven months later, one of these stations, a high-energy site, showed some signs of recovery, but this process was not observed at the other, which seemed to be a low-energy site. In conclusion, the data showed that the aliphatic hydrocarbon analyses were powerful tools for the assessment of the fate of the oil spill and that the northern part of the São Sebastião Channel is more subject to the effects of oil spills.
\end{abstract}

\section{RES UMO}

A ruptura de um oleoduto em maio de 1994 introduziu 2.700 tons de óleo cru no Canal de São Sebastião, contaminando algumas áreas. Na ocasião um monitoramento de hidrocarbonetos em sedimentos estava sendo realizado na região, utilizando o método de cromatografia em fase gasosa/ detecção por ionização de chama. Os dados obtidos nesse monitoramento foram comparados aos resultados das amostras coletadas logo após o acidente, com o objetivo de verificar a extensão da contaminação por óleo e os lugares mais atingidos. Os dados prévios mostraram duas fontes de introdução de hidrocarbonetos: biogênica, com predomínio de plantas superiores, e antrópica, causada por atividades náuticas e esgotos. Os dados posteriores mostraram que a estação de coleta mais próxima ao oleoduto foi a mais atingida. Na sequencia, as duas estações localizadas na entrada norte do canal apresentaram as maiores concentrações de n-alcanos, sugerindo que as correntes NE, impulsionadas pelo vento, transportaram o óleo no sentido norte do canal. Sete meses depois uma destas estações, aquela situada em local de alta energia, mostrou sinais de recuperação, o que, contudo, não foi observado na outra, considerada de ambiente deposicional. Em conclusão, pode-se afirmar que análises de hidrocarbonetos são ferramentas poderosas para avaliar o destino de um óleo e que a parte norte do Canal de São Sebastião tem maior probabilidade de ser afetada na ocasião de um derrame de óleo.

Descriptors: Oil spill fate, Pipeline rupture, Petroleum hydrocarbons, Sediment, São Sebastião Channel, Brazil.

Descritores: Destino de óleo derramado; Ruptura de oleoduto, Hidrocarbonetos de petróleo, Sedimento, Canal de São Sebastião, Brasil.

\section{INTRODUCTION}

Human influence in coastal areas has been widely recognized throughout the world and there is an increasing awareness of the emergent problem and the probability of exposure to potential risks. Environmentalists and government agencies have expressed great concern about the possible impact of this situation on living organisms as well as on the population itself. Petroleum is commonly pointed to as an important coastal contaminant mainly because its 
introduction may be either chronic or accidental. Chronic introduction is generally small but, since it is continuous, its impact could be as harmful as or even greater than that caused by an oil spill (CRIPPS; SHEARS, 1997; MORALES-CASELLES et al., 2008). In general, accidents are responsible for great but localized oil spillages and can lead to ecological disasters, characterized by loss of species richness and the degradation of mangrove areas and other ecotopes, sediment quality, and impact offshore fish and crustacean fisheries (DE LA HUZ et al., 2005; SÁNCHEZ et al., 2006; MORALESCASELLES et al., 2007; MELVILLE et al., 2009; PENELA-ARENAZ et al., 2009).

However, the magnitude of the effects on sediments and their associated benthic organisms will depend greatly on variations in local environmental factors such as temperature, solar radiation, exposure to water, and the amount of oil spilt (ATLAS, 1981 apud LEMKAU, et al. 2010). Also, the chemical composition of the oil and the level of biodegradability of its compounds, i.e., their ability to persist in the marine environment, associated with the level of acute toxicity will determine the potential severity of the hazard (GESAMP, 2002; YIM et al., 2011). In addition, the environmental health of the location before the accident might also contribute to its observed effects. Nonetheless, some biological processes such as bioturbation and microbial (bacterial and fungal) degradation would also influence the fate of the contaminants in the sediments (ATLAS, 1981 apud LEMKAU et al., 2010).

Hydrocarbons are the predominant constituent compounds of oil and may thus be used as indicators of this type of contamination. However, they can also be introduced into the environment from biogenic sources (VOLKMAN et al., 1992). The origin of hydrocarbons can be inferred from the distribution of individual compounds and defined by a set of diagnostic criteria capable of distinguishing the respective contribution of biogenic and anthropogenic hydrocarbons. The relative distribution of aliphatic hydrocarbons is used as an indicator of the presence of petroleum hydrocarbons in sediments mainly because these compounds comprise a large fraction of the total hydrocarbons (VOLKMAN et al., 1992). The natural contribution of individual n-alkanes to the environment is predominantly of the odd carbon numbered chain and petroleum sources show no predominance of odd or even carbon numbers (NRC, 2003; VOLKMAN et al., 1992). Therefore, an odd to even ratio should be helpful in identifying the source of the hydrocarbons in the sediments seeing that this value is approximately 1.0 for petroleum. Terrestrial plants contribute longer odd-chain hydrocarbons such as $n-C_{23}$ to $n-C_{33}$ to the environment whereas phytoplankton releases shorter odd-chain ones, such as
$\mathrm{n}-\mathrm{C}_{15}$ to $\mathrm{n}-\mathrm{C}_{21}$ (VOLKMAN et al., 1992). The isoprenoid hydrocarbons pristane and phytane are also useful in the investigation of the origin of the hydrocarbons found in sediments. Pristane occurs naturally in oxidative environments as a degradation product of the phytol side chain of chlorophyll and both of them are commonly found in petroleum products. The ratio of pristane to phytane (pri/phy) is, therefore, usually greater than 1.0 in biogenic samples, and around 1.0 in sediments contaminated by petroleum (VOLKMAN et al., 1992). However, values less than one are not indicative of the presence of petroleum (HUMPHREY et al., 1987). The biodegradation within samples can be examined by monitoring the loss of more labile n-alkanes relative to more recalcitrant branched isoprenoid alkanes (PETERS et al., 2005; LEMKAU et al., 2010). Another feature used as indicative of petroleum hydrocarbons is the presence of the unresolved complex mixture (UCM), which is the most abundant, ubiquitous, and understudied class of organic contaminants in estuarine and coastal sediments. The term UCM is derived from traditional gas chromatography and refers to an increase of the baseline or hump of unresolved and, hence, unidentified hydrocarbons in gas chromatograms. The UCM is especially pronounced for biodegraded petroleum and certain refined fractions such as lubricating oils 1-4 (GOUGH; ROWLAND, 1990).

In areas under potential accident risk it is difficult to distinguish the contribution of the chronic introduction of oil from that of spillages, unless previous data provide a local baseline. These areas are, therefore, constantly focused on in monitoring programs. Predicting oil spill fate and the time necessary to recover the environment are important tools to help in taking actions during or right after the spillage to avoid or minimize the damage caused, even though it is a hard task to establish it correctly. Several modeling studies have been applied to understand the trajectory of an oil contamination episode and its effect on organisms (SOTILLO et al., 2008; CHRASTANSKY; CALLIES, 2009; CHRASTANSKY et al., 2009; GUO et al., 2009; LEMOS et al., 2009), but the various environmental parameters considered might make these models inapplicable or difficult to interpret. Another way to understand and predict an oil spill's fate is to observe actual cases occurring in the area concerned during preceding years (POFFO et al., 2001).

This paper reports a once-only study of aliphatic hydrocarbons in the sediments of a Brazilian coastal area: the São Sebastião Channel (SSC). It is the first study undertaken to show the fate of an oil spill in the SSC and defines the areas most affected within the channel, based on the variation of the 
petroleum hydrocarbon concentrations in sediments before, right after and some months after the spillage. Study Area

The São Sebastião Channel (SSC) is located in São Paulo State and is bordered by the municipalities of Ilhabela (island) and São Sebastião (mainland), as can be seen in Figure 1. This channel is $25 \mathrm{~km}$ long and 2 to $6 \mathrm{~km}$ in width, the water depth being $20-25 \mathrm{~m}$ at the entrances and up to $40 \mathrm{~m}$ in the central part. These characteristics make this channel an excellent harbor for tankers of up to 300000 ton displacement. In 1967, an important oil terminal DTCS (Dutos e Terminal Centro Sul) - was installed on this channel (Fig. 1) and nowadays is the biggest in Brazil and accounting for a large proportion of all Latin American activity. This oil terminal is a significant chronic and accidental source of petroleum hydrocarbon contamination in the area. Shipping operations introduce petroleum into this environment constantly. Further, a total of 232 petroleum accidents were registered there between 1974 and 2000, including shipwrecks, oil pipeline leakages and those related to normal oil terminal activities (POFFO et al., 2001). In addition, illegal activities such as discharges from ship engine rooms and residues from tank washing appear also to contribute to the oil contamination of this channel (ZANARDI et al., 1999a). According to Poffo et al. (2001), among chronic and accidental inputs, shipwreck is the most frequent cause of oil introduction into the SSC (36\%), followed by shipping operational and mechanical failures $(22 \%$ and $19 \%$, respectively).

In May 1994, a rupture occurred in the oil pipeline of the DTCS, which runs parallel to the continental side of the SSC, and 2700 tons of crude oil leaked into the channel, affecting 17 beaches in São Sebastião City and 11 on Ilhabela (CETESB, 1994a). In that same year, a monitoring program had been undertaken in the SSC to investigate the spatial and temporal distribution of dissolved/dispersed petroleum aromatic hydrocarbons in the water, and the results, including those resulting from previous oil spills, had already been published (ZANARDI et al., 1999 b). Parallel to that, the aliphatic hydrocarbons in sediments were also investigated and the data describing the contamination level before and after this major accident will be presented below. The results could, further, indicate where most of the oil sedimentation inside the channel occurred.

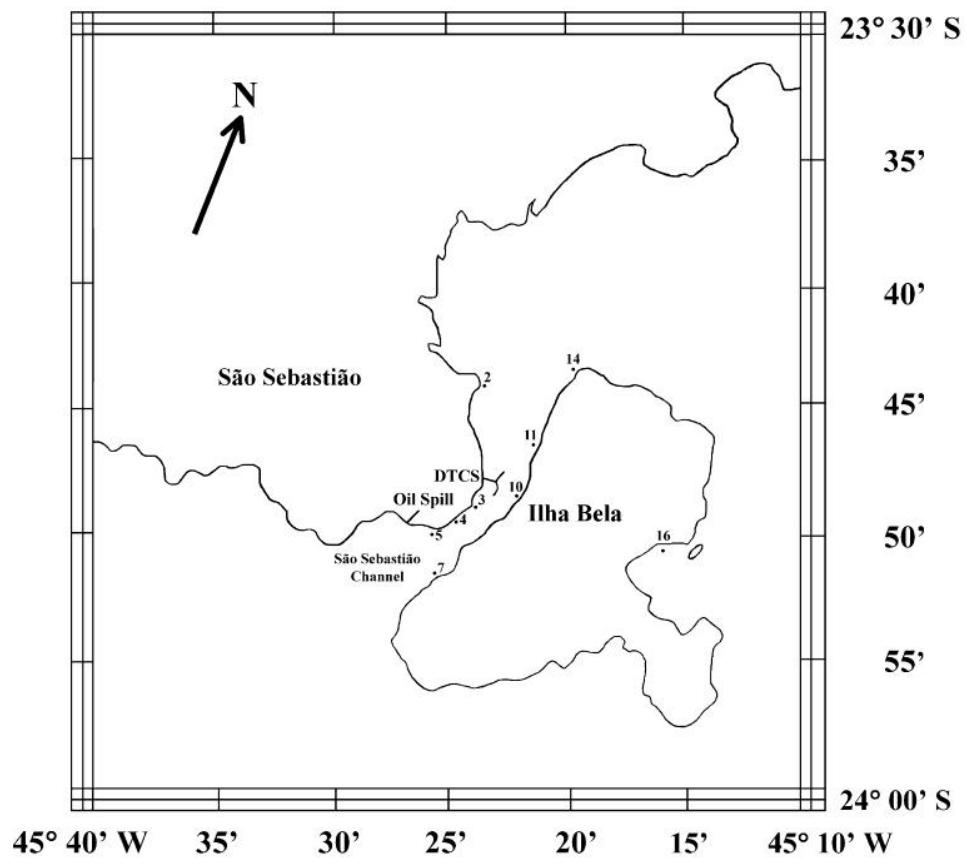

Fig. 1. Sediment sampling sites inside the São Sebastião Channel (SSC), sampled in October 1993, March, June and December 1994. The oil terminal (DTCS) and the oil spill location are shown. 


\section{Material and Methods}

This study was part of a monitoring program whose objective was to sample sediments approximately every six months (October and March) over 2 years. Parallel to it, there was a rocky shore monitoring program, designed to evaluate oil spill disturbance of biological communities (LOPES et al., 1997). The sediment sampling sites (Fig. 1) were chosen so they would be close to the rock communities studied and provide information about oil contamination at those locations. According to the group, an increase in sediment hydrocarbon concentration, after a 6-month interval, would be enough for observing effects, if any, on the biological community. To achieve this, the first two cruises were undertaken in October 1993 and March 1994. After the oil spill (May 1994), the next two sampling periods were brought forward to June and December 1994. The cruises were made by the RV. Diana of the São Paulo State Environmental Agency (CETESB) and sediments were collected using a modified Petersen grab, samples being taken from the center of the grab to a depth of $2 \mathrm{~cm}$. In October 1993, 8 locations were sampled and, after March 1994, a new sampling site was included in the reference area station \#16. This site was considered suitable as a reference site because it is located in a protected area, ocean ward of the Island and distant from the channel, thus reducing the probability of its being contaminated by oil spill events. St \#16 has a grain size distribution similar to that of some of the other stations studied and, unfortunately, no other place was found, suitable as a second reference site, with different granulometric distribution and low oil contamination.

Samples were kept at $-15^{\circ} \mathrm{C}$ until laboratory analysis. After drying in an oven at $50^{\circ} \mathrm{C}, 25 \mathrm{~g}$ of the sample was spiked with $5 \mu \mathrm{g}$ of n-octadecene as the internal standard and Soxhlet extracted with a $50 \%$ mixture of $n$-hexane and dichloromethane for eight hours. After extraction, pellets of copper were used to remove sulfur compounds. The organic extracts were concentrated on a rotary evaporator and purified by silica/alumina gel chromatography (5\% deactivated in water). $\mathrm{N}$-alkanes and the isoprenoid hydrocarbons pristane and phytane, were analyzed in the extracts.

Hydrocarbons were determined on a Hewlett Packard 5890 II high-resolution gas chromatograph with flame ionization detection, equipped with an Ultra II SE54 capillary column. The oven temperature was programmed to ramp from $40-60^{\circ} \mathrm{C}$ at $20^{\circ} \mathrm{C} \mathrm{min}^{-1}$ and $60-300^{\circ} \mathrm{C}$ at $4^{\circ} \mathrm{C} \mathrm{min}^{-1}$ with hydrogen as carrier gas. The instrument was calibrated by the injection of certified standards at five different concentrations. Calibration curve checks were performed routinely, once a week. Individual n-alkanes and isoprenoids identification was based on GC retention times. All the solvents were pesticide grade, and the blanks were checked under the same conditions as those of the analyses and the concentration obtained was subtracted from all samples. The method detection limit (DL) was based on the standard deviation $(3 \mathrm{x})$ of eight blanks, according to Quevauviller et al. (1992) and Maynard (1990). The results varied from 0.005 to $0.018 \mu \mathrm{g} \mathrm{g}^{-1}$ for the individual compounds and was $0.035 \mu \mathrm{g} \mathrm{g}^{-1}$ for total n-alkane. Quantification was performed using internal standards, which were added to all the samples and blank prior to the extraction process. The complete analytical protocol has been described in detail by UNEP (1992) and elsewhere (BÍCEGO et al. 1998; 2009).

The granulometric analysis of the sediments was performed by the sieve-pipette method, according to the procedure described in Suguio (1973), and the results were expressed as \% of mud (silt + clay) and \% sand. The Origin 6.0 program was used for the statistical analyses and graph construction.

\section{RESULTS}

\section{HCs Prior to the Oil Spill}

The sediment sampled prior to the accident showed an aliphatic hydrocarbon distribution of similar patterns to that of Figure 2, where the whole series studied is present but the higher odd-carbonchain dominates. An exception is the sample from St \#7 that presented a different distribution, in October 1993, and will be discussed below. The total n-alkane concentration was calculated considering the individual concentrations of compounds with 12 to 35 carbons in the chain, and ranged from 0.34 to $2.35 \mu \mathrm{g}$ $\mathrm{g}^{-1}$ in October 1993 and from 0.19 to $2.70 \mu \mathrm{g} \mathrm{g}^{-1}$ in March 1994 (Table 1). The highest concentrations were registered in sediments from Sts \#2, \#3, \#10, \#11 and $\# 14$, with concentrations above $1.35 \mu \mathrm{g} \mathrm{g}^{-1}$. The pristane and phytane isoprenoids were also identified in these sediments, and the ratio pri/phy varied from 0.8 to 2.2 (Table 1 ). The grain size distribution of these samples ranged from 24.0 to $91.5 \%$ of mud (Table 2). The sediments from the reference site ( $\mathrm{St}$ \#16) and from the southern entrance of the channel, Sts \#4, \#5 and \#7, sampled in October 1993 and March 1994, presented total n-alkane concentrations varying from 0.19 to $1.16 \mu \mathrm{g} \mathrm{g}^{-1}$ (Table 1 ) and none of the isoprenoids was reported. These sediments were predominantly sand (Table 2 ).

\section{After the Oil Spill June 1994}

A month after the oil spill, the stations studied were sampled to verify the presence of oil in the sediments. Unfortunately, the sediments from the site 
closest to the spillage (St \#5) could not be investigated as they were lost due to a failure in the laboratory's freezing system. The total n-alkane concentration ranged from 0.09 to $4.86 \mu \mathrm{g} \mathrm{g}^{-1}$ (Table 1) and the UCM was registered in all sediment samples, except that from St \#16 (reference site). The most contaminated sites were St \#2 $\left(2.59 \mu \mathrm{g} \mathrm{g}^{-1}\right)$ and St \#14 $\left(4.86 \mu \mathrm{g} \mathrm{g}^{-1}\right)$, located on the opposite side to the oil spillage, in the north of the SSC. These concentrations were, respectively, $75 \%$ and $261 \%$ higher than those reported in March of that same year. The UCM was very evident in these sediments and clearly indicated an introduction of oil, as can be seen in the sediment chromatogram from St \#14 (Fig. 3). The pristane and phytane concentrations were similar to those of the months previously studied, and the ratio pri/phy for Sts \#2 and \#14 was around 1 (Table 1). In spite of the impact of the oil spill, the compounds from terrestrial plants, $\mathrm{n}-\mathrm{C}_{27}, \mathrm{n}-\mathrm{C}_{29}, \mathrm{n}-\mathrm{C}_{31}$ and $\mathrm{n}-\mathrm{C}_{33}$ (VOLKMAN et al., 1992) were also observed in higher concentrations than before.

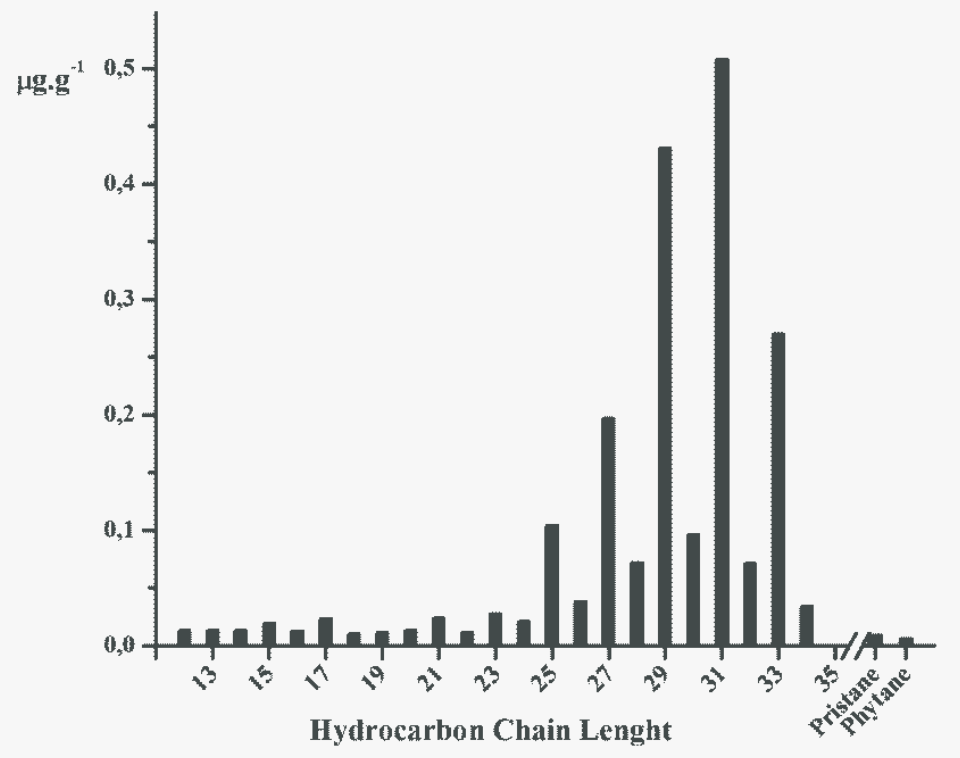

Fig. 2. Hydrocarbon profile for sediments collected in the São Sebastião Channel (SSC) in October 1993 and March 1994.

Table 1. Total n-alkane concentration (n-alk, $\mu \mathrm{g} \mathrm{g}^{-1}$ ) and pristane/phytane (pri/phy), odd/even, and $\mathrm{C}_{17} /$ pri ratios in sediments from São Sebastião Channel collected from October 1993 to December 1994.

\begin{tabular}{|c|c|c|c|c|c|c|c|c|c|c|c|c|c|c|c|c|}
\hline \multirow[b]{2}{*}{ St } & \multicolumn{4}{|c|}{ October 1993} & \multicolumn{4}{|c|}{ March 1994} & \multicolumn{4}{|c|}{ June 1994} & \multicolumn{4}{|c|}{ October 1994} \\
\hline & n-alk & $\begin{array}{l}\text { pri/ } \\
\text { phy }\end{array}$ & $\begin{array}{l}\text { odd/ } \\
\text { even }\end{array}$ & $\begin{array}{c}\mathrm{C}_{17} / \\
\text { pri }\end{array}$ & $\begin{array}{l}\text { n- } \\
\text { alk }\end{array}$ & $\begin{array}{l}\text { pri/ } \\
\text { phy }\end{array}$ & $\begin{array}{l}\text { odd/ } \\
\text { even }\end{array}$ & $\begin{array}{l}\mathrm{C}_{17} / \\
\text { pri }\end{array}$ & n-alk & $\begin{array}{l}\text { pri/ } \\
\text { phy }\end{array}$ & $\begin{array}{l}\text { odd/ } \\
\text { even }\end{array}$ & $\begin{array}{l}\mathrm{C}_{17} / \\
\text { pri }\end{array}$ & n-alk & $\begin{array}{l}\text { pri/ } \\
\text { phy }\end{array}$ & $\begin{array}{l}\text { odd/ } \\
\text { even }\end{array}$ & $\begin{array}{l}\mathrm{C}_{17} / \\
\text { pri }\end{array}$ \\
\hline$\# 2$ & 2.35 & 1.8 & 2.4 & 1.7 & 1.48 & 1.2 & 4.6 & 1.4 & 2.59 & 0.9 & 4.9 & 2.5 & 3.72 & 1.2 & 5.3 & 2.7 \\
\hline$\# \mathbf{3}$ & 1.41 & 1.3 & 2.3 & 1.7 & 1.53 & 1.9 & 2.8 & 1.9 & 0.22 & - & 2.6 & 2.5 & 1.35 & 1.5 & 2.5 & 1.3 \\
\hline$\# 4$ & 0.34 & - & 2.4 & - & 1.16 & 2.7 & 6.4 & 1.3 & 0.55 & 0.6 & 4.9 & 1.7 & 0.57 & 1.4 & 4.9 & 2.8 \\
\hline$\# 5$ & 0.51 & - & 2.3 & - & 0.77 & - & 4.9 & - & n.a. & n.a. & n.a. & - & 5.98 & 1.0 & 1.6 & 0.02 \\
\hline$\# 7$ & 0.47 & - & 1.1 & - & 0.19 & - & 6.5 & - & 0.13 & - & 5.0 & - & 0.04 & - & 5.9 & - \\
\hline$\# 10$ & 1.82 & 2.2 & 3.6 & 2.0 & 0.47 & - & 5.1 & - & 0.56 & - & 6.4 & - & 0.36 & - & 5.2 & - \\
\hline$\# 11$ & 1.79 & 1.3 & 3.8 & 2.4 & 2.70 & 0.8 & 4.6 & 3.2 & 1.72 & - & 6.2 & - & 3.36 & 0.7 & 5.1 & 4.6 \\
\hline$\# 14$ & 2.03 & 1.5 & 4.0 & 2.4 & 1.34 & 1.6 & 5.0 & 2.9 & 4.86 & 1.7 & 5.2 & 5.0 & 3.22 & 1.9 & 5.5 & 3.4 \\
\hline$\# 16$ & n.s. & n.s. & n.s. & & 0.25 & - & 4.8 & - & 0.09 & - & 15.8 & - & n.d. & - & n.d. & - \\
\hline
\end{tabular}

n.a. $=$ Not analyzed; n.d. $=$ Not detected; $-=$ Not possible to calculate 
Table 2. Granulometric distribution of sediments from São Sebastião Channel collected from October 1993 to December 1994.

\begin{tabular}{|c|c|c|c|c|c|c|c|c|}
\hline \multirow{2}{*}{$\begin{array}{l}\text { Year \ } \\
\text { Station }\end{array}$} & \multicolumn{2}{|c|}{ October 1993} & \multicolumn{2}{|c|}{ March 1994} & \multicolumn{2}{|c|}{ June 1994} & \multicolumn{2}{|c|}{ December 1994} \\
\hline & sand $\%$ & $\operatorname{mud} \%$ & sand\% & mud \% & sand \% & $\operatorname{mud} \%$ & sand\% & mud \% \\
\hline$\# 2$ & 8.5 & 91.5 & 8.5 & 91.5 & 23.7 & 76.3 & 31.3 & 68.7 \\
\hline$\# 3$ & 70.7 & 29.4 & 10.2 & 89.8 & 60.4 & 39.6 & 29.7 & 70.3 \\
\hline$\# 4$ & 92.0 & 8.0 & 71.9 & 28.1 & 93.4 & 6.7 & 87.0 & 13.1 \\
\hline$\# 5$ & 93.3 & 6.7 & 95.2 & 4.8 & - & - & 12.4 & 87.6 \\
\hline$\# 7$ & 92.9 & 7.1 & 94.6 & 5.4 & 96.8 & 3.2 & 99.1 & 0.9 \\
\hline$\# 10$ & 68.0 & 32.0 & 65.1 & 34.9 & 63.7 & 36.3 & 62.2 & 37.8 \\
\hline$\# 11$ & 53.1 & 46.9 & 59.9 & 40.1 & 59.9 & 40.1 & 54.4 & 45.6 \\
\hline$\# 14$ & 59.5 & 40.6 & 76.1 & 24.0 & 69.1 & 30.9 & 67.6 & 32.4 \\
\hline$\# 16$ & n.s. & n.s. & 77.6 & 22.4 & 83.8 & 16.2 & 86.8 & 13.2 \\
\hline
\end{tabular}

n.s. $=$ not sampled
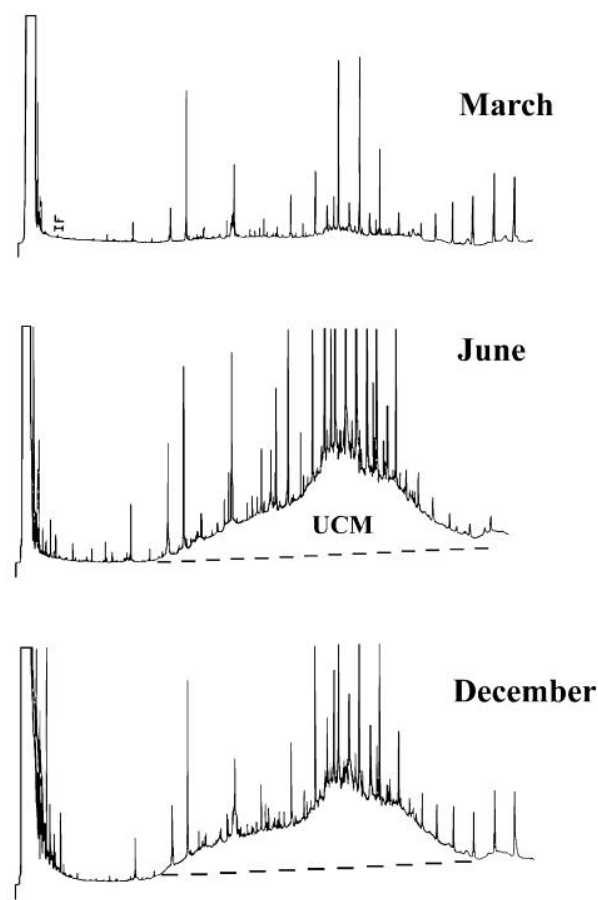

Fig. 3. Chromatograms of sediments from St \#14, sampled in March, June and December 1994. Unresolved Complex Mixture (UCM) can be visualized in June and December sediments.

The total n-alkane concentrations in the sediments from Sts \#3, \#4, \#7, \#10 and \#16 were low and varied between $0.09-0.56 \mu \mathrm{g} \mathrm{g}^{-1}$, and St \#11 had $1.72 \mu \mathrm{g} \mathrm{g}^{-1}$ of $\mathrm{n}$-alkane. This location also presented a well-developed UCM (Fig. 4), higher than that of the sampling of the former period.
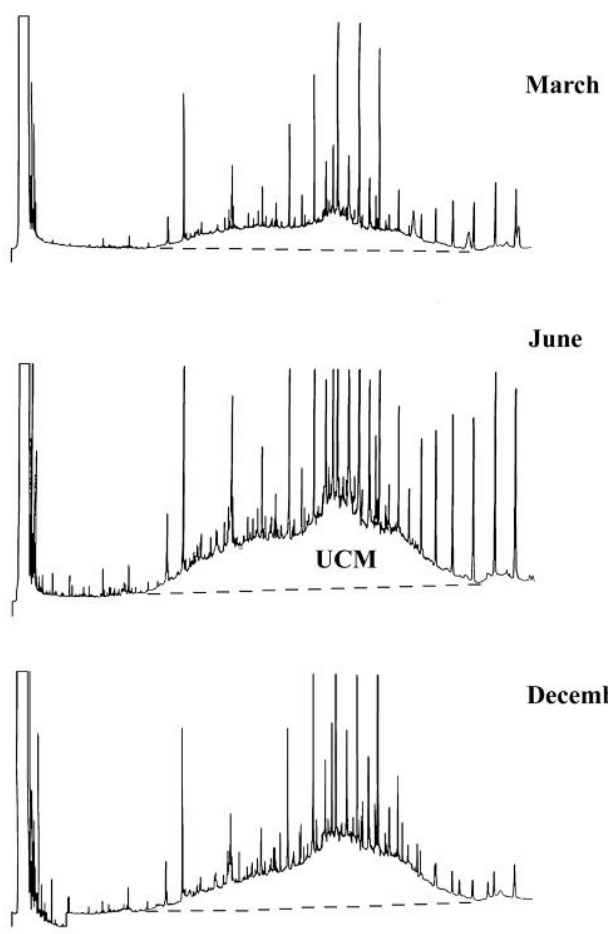

December

Fig. 4. Chromatograms of sediments from St \#11, sampled in March, June and December 1994. Unresolved Complex Mixture (UCM) can be visualized in the three months analyzed.

\section{December 1994}

Seven months after the oil spillage, the sediments were again investigated. The total $\mathrm{n}$-alkane at St \#5, $5.98 \mu \mathrm{g} \mathrm{g}^{-1}$, was the highest among the sediments collected in this period (Table 1). The isoprenoid hydrocarbons pristane and phytane, the most abundant compounds found (Table 1), were 
present in very high concentrations - of 3.43 and 3.32 $\mu \mathrm{g} \mathrm{g}^{-1}$, respectively. A huge UCM was observed in the chromatogram of a 10 times-diluted extract containing aliphatic hydrocarbons from St \#5 (Fig. 5). The chromatogram shows a UCM during the whole sequence, different from that for the other sediments.

Following St \#5, the stations \#2, \#11 and \#14 presented the highest total n-alkane concentrations in the December samples, ranging from 3.22 to $3.72 \mu \mathrm{g}$ $\mathrm{g}^{-1}$ (Table 1). A well-developed UCM was also observed at these stations (Figs 3 and 4). The sediment size distribution was approximately similar to that of the sediments sampled in the previous months (Table 2 ), thus allowing a direct comparison between the sampling periods. In fact, the concentrations at Sts \#2 and \# 11 in December were even higher than in June, the month after the oil accident. The stations \#4 and $\# 7$, located at the southern entrance, and Sts \#3 and \#10 had characteristics similar to those found before the oil spill. All compounds were below the detection limit in sediments from St \#16 (Table 1).

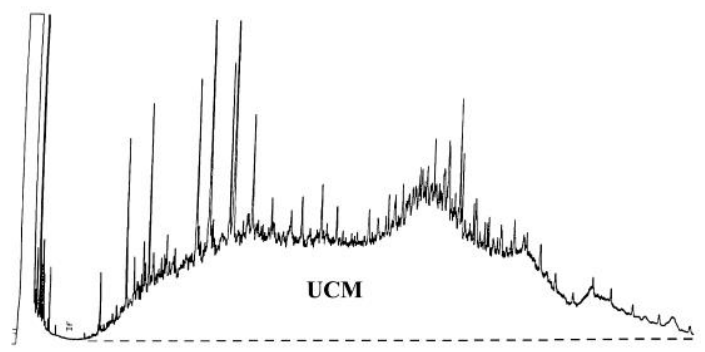

Fig. 5. Chromatogram of sediments from St \#5, sampled in December 1994. The extract was diluted 10 times.

\section{Statistical Results}

The statistical results showed a positive and significant correlation between $\mathrm{n}$-alk and $\%$ mud (Pearson's $r=0.60, p=0.0003$, d.f. $=32$, Figure 6). The $\%$ variation of mud explained $35 \%$ of the n-alk variation among the locations. Some stations showed the oil contribution after the accident more clearly than others. St \#14, for example, presented the same mud $\%$ but a higher $n$-alkane concentration (positive residuals) after the oil spill. Similar behavior was observed at St \#2, with positive residuals 7 months after the accident. Three different situations could be observed according to the $\%$ of mud in the sediments (Fig. 6): a) St \#2 (northern entrance of the channel), a depositional area with high percentages of mud and relatively high n-alkane concentration; b) Stations \#4, \#5 and \#7, located at the southern entrance, with low mud $\%$ and lower n-alkane concentrations than those of the other sites studied, and c) a third situation, characterizing Sts \#10, \#11 (central part) and \#14 (northern entrance), which had an intermediate percentage of mud $(\sim 40 \%)$ and variable n-alkane concentration (Fig. 6). St \#16 presented similar characteristics to the second group. Sediments from $\mathrm{St}$ \# 3 have not been included in the statistics because the grain size distribution was so different among the sampled periods as to suggest that they were samples from different locations. The data comparison would be unrealistic (Dr. TESSLER, pers. comm.). The data from $\mathrm{St} \mathrm{\# 3}$ is, however, presented in this study for characterization purpose only.

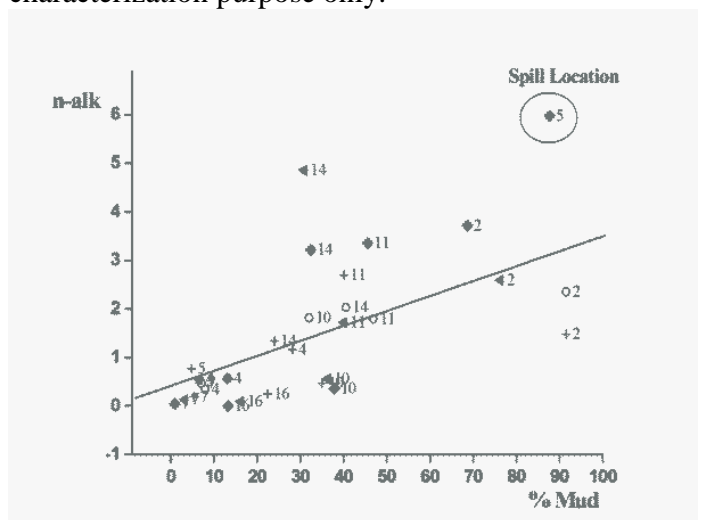

Fig. 6. Total $\mathrm{n}$-alkane concentration $\left(\mathrm{mg} \mathrm{g}^{-1}\right)$ vs \%mud of sediments from São Sebastião Channel with $r=0.60$. Numbers represent the sampling stations and symbols refer to: Oct $/ 93=0 ;$ March/94 = +; Jun/94 = ४; Dec/94 = .

\section{Discussion}

Prior to the Oil Spill: Hydrocarbon Characterization of SSC

The concentrations reported for the sediments sampled before the oil spill are low when compared to samples from polluted urbanized areas, and are similar to those registered in some unpolluted sediments (VOLKMAN et al., 1992; SNEADAKER et al., 1995; MAIOLI et al., 2010). In addition, the total n-alkane concentrations in this period were similar to those reported in a study conducted in the surrounding area (ZANARDI et al., 1999a). According to a circulation study (CASTRO et al., 2008), there is a predominance of northeasterly wind-driven currents during the winter, which could carry the contaminants from all the activities undertaken inside the channel towards the northern entrance. Grain size is also very important in contamination studies because the adsorptive capacity is related to the effective surface area: finer particles have greater effective area, and therefore, higher adsorptive capacity (LAW, 1981). Sediments collected from the northern region of the SSC (Sts \#2, $\# 11$ and \#14) had higher percentages of fine particles than those associated with the predominant northward currents, which could explain the higher hydrocarbon concentrations reported in these areas as compared to 
the those at the southern entrance of the SSC (Table $1)$.

The odd-to-even carbon number ratios, in the majority of the samples studied, were higher than 2.3 (Table 1), suggesting biogenic hydrocarbon sources. The predominance of long chain higher than $n-C_{27}$ (Fig. 2) indicates mainly terrestrial plant input. In fact, the sediments were taken from sites located close to the coastline characterized by luxuriant Atlantic Forest vegetation. On the other hand, the presence of all the aliphatic hydrocarbons studied suggests that, even though the main contribution is from terrestrial natural plants, there is also a small petroleum contribution. The UCM registered during the chromatographic analyses of sediments from Sts \#2, \#3, \#10 and \#11 (October 1993 and Mach 1994) reinforce the case for petroleum influence (see, for example, Figure 4). Besides, the greater than 1 pri/phy ratio reported for these locations inside the SSC (Table 1) is also typical of an oil contribution (VOLKMAN et al., 1992). These sets of data indicate that the central and northern parts of the SSC receive both a biogenic and an anthropogenic hydrocarbon contribution.

In contrast, the sediments collected at the southern entrance of the SSC presented lower hydrocarbon concentrations (Table 1). This is probably due to the grain size of these sediments that are predominantly sand (Table 2 ) which has the lower adsorptive capacity associated with the predominantly northerly currents. Interestingly, the sediments from $\mathrm{St}$ \# 7 presented a very well developed UCM and, in addition, an unusually homologous n-alkane series (nC >35) was also observed (Fig. 7). This kind of contribution is rarely found and is associated with weatherized oil (Dr. EHRHARDT, pers. comm.).

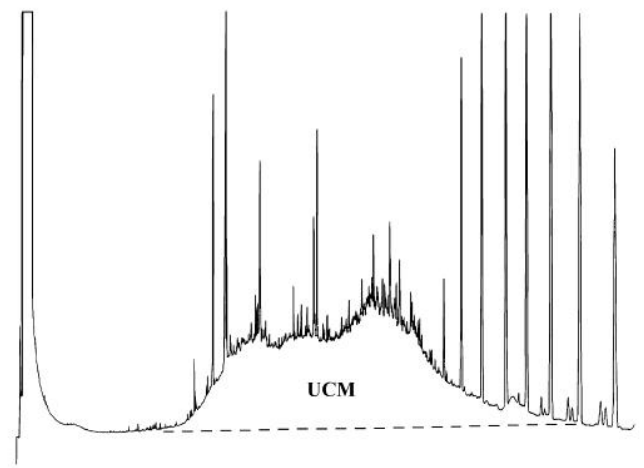

Fig. 7. Chromatogram of sediments from St \#7, sampled in October 1993. A well-developed Unresolved Complex Mixture (UCM) and an unusual homologous n-alkane series $(n-C>35)$ is shown.

Several sources of organic contaminants had been registered in this channel during previous research (CETESB, 1994b; ZANARDI et al., 1999a and b; POFFO et al., 2001). According to CETESB (1994b), there is an untreated sewage discharge from a submarine emissary near St \#3. This point is close to the DTCS and São Sebastião port, where their effluents are discharged into the channel. Also, Zanardi et al. (1999b) reported that the concentration of hydrocarbons dissolved and dispersed in water was highest at this point in the channel. At St \#5 there are several water outflows that carry domestic sewage during the summer (rainy) season (CETESB, 1994b). In the proximity of St \#10 there is a shipyard, where small boats are washed and repaired, and the detritus and residue are discharged into the sea (ZANARDI et al., 1999b). In addition, this sampling site is located a little south of the ferryboat station that connects the island to the mainland and operates continuously. A nautical club, formerly Clube Ilhabela, located at St \#11, contributes with both burnt and crude oil from its boats and Zanardi et al. (1999b) already reported its oil contribution to the surrounding waters. There are four small water outflows between St \# 11 and St \#14 that carry domestic sewage to the ocean, mainly during the summer (rainy) season, when tourist activities are at their most intense. In addition, there are a few others sources of oil at St \#2: the domestic sewage from the neighborhood enters the sea through a submarine emissary; two brooks bring the residues from two gas stations close to that beach; a nautical club uses this beach (St \#2) to launch their boats (CETESB, 1994b). As the predominant currents in this Channel are from south to north (CASTRO et al., 2008), it is to be expected that the sites located in the north should receive most of the contaminated water from all the aforementioned sources located in the channel. However, the northeasterly winds generate currents that may carry pollutants southward, thus contaminating the adjacent areas (CASTRO et al., 2008).

The sediments from the reference site were predominantly sand, and presented a total $\mathrm{n}$-alkane concentration as low as $0.25 \mu \mathrm{g} \mathrm{g}^{-1}$ (Table 1) with a predominance of long-odd-chain hydrocarbons. Since neither UCM nor isoprenoids were observed, the data suggest that the hydrocarbons are mainly derived from terrestrial material.

\section{After the Oil Spill June 1994}

According to Zanardi et al. (1999b), the oil spilt from the pipeline in May 1994 was driven mainly to the north of the channel due to the prevailing local circulation. Those authors observed a high petroleum concentration, 4 days after the accident, in the water round Sts \#2 and \#14. The present study also found the highest n-alkane concentrations in sediments 
sampled at those stations (Table 1), in agreement with the above mentioned work. The low n-alkane concentration reported for sediments from Sts \#4, \#7 and \#10 suggests that these sediments were not affected by the spillage or received but a small contribution. St \#11 presented a lower n-alkane concentration than in previous months, but registered a higher UCM (Fig. 4), which could be an evidence of the introduction of oil. According to CETESB (1994a); Poffo et al. (1996), on the third day (May 17) some oil was seen around St \#11 and ten days after the spill there was still a film of oil covering the channel, including St \#7 at its southern entrance. The authors attributed this fact to an inversion of the predominant current pattern. Zanardi et al. (1999b) reported the presence of oil on the water surface of the entire channel, differently from the results observed in the sediments, reinforcing the importance of sediment studies that reveal long-term contamination. The oil did not reach the sediments at the reference site (St \#16), located outside the channel, and its presence was not registered, even in the water (ZANARDI et al. 1999b). These results show that the oil spilt affected the sediments at the northern sites of the SSC most.

\section{December 1994}

St \#5 is the closest site to the pipeline rupture and located in the most contaminated area in the SSC. This is corroborated by the fact that the total n-alkane there is 6.7 times higher than the concentrations reported for the same site sampled in March (Table 1). The pristane and phytane were the most abundant compounds in this sediment, indicating a recent introduction of oil. These concentrations, higher than those of other compounds, probably occurred because the branched hydrocarbons, such as the isoprenoids, degrade more slowly than n-alkanes (NRC, 2003). Further, the unusual UCM level observed in the chromatogram of the sediments from St \#5 (Fig. 5), with n-alkanes from $n-C_{13}$ through the whole series analyzed up to $n-C_{35}$, is typical of sediments recently contaminated by petroleum, though the degradation is still low (READMAN et al., 1986). And, finally, a significant oil film could be observed visually on the sediment sampled, confirming the high degree of contamination and the persistence of the oil spilt on these sediments.

The average concentration and the standard deviation of total $n$-alkane were calculated for the two sets of samples collected before the accident in the attempt to minimize the differences due to sampling errors. These data as well as the concentration obtained in sediments sampled after the oil spill, in June and December 1994, are presented in Figure 8. The increasing concentration in the samples from $\mathrm{St}$
\#5 (spillage location) is remarkable. Sts \# 2 and \#14 also responded to the accident with positive residuals (higher n-alkane concentration than was expected) as shown in Figure 6, proving the fate of the oil spilt. However, the oil did not persist in sediments from the high-energy area (St \#14) as long as it did in those from depositional areas such as represented by St \#2 (Fig. 8). The concentrations at St \#14 decreased from 4.86 to $3.22 \mu \mathrm{g} \mathrm{g}^{-1}$ ( 34\%), between June and December, in contrast to the increasing concentration observed at St \#2, from 2.59 to $3.72 \mu \mathrm{g} \mathrm{g}^{-1}$ ( 44\%), for the same period. A deposition rate study is necessary to make it possible for conclusions to be drawn from these facts. However, knowing the area and judging from the sediment composition (almost $70 \%$ sand), St \#14 may be considered to represent a high-energy area which received the contaminants and, after 7 months, had already begun a recovery process. The decrease of $n-C_{17} /$ pristane and $n$ $\mathrm{C}_{18}$ /phytane ratios is commonly used as an early indicator of biodegradation (PETERS et al., 2005; LEMKAU et al., 2010). The observed decreased of the n- $\mathrm{C}_{17} /$ pristane ratio for $\mathrm{St} \# 14$ confirms the undergoing biodegradation process (Table 1). It was not possible to calculate the $\mathrm{n}-\mathrm{C}_{18}$ /phytane ratio because the $n-C_{18}$ concentration (data not shown) was below the detection limit. Sediments from St \#2, consisting basically of mud (approximately 70\%), represent a low-energy environment, and the sedimentation rate of these fine particles may be presumed to be lower than that of coarse particles (St \#14). If true, that would explain the smaller hydrocarbon concentrations in June than at St \#14 in the month following the oil spillage. No loss of more labile n-alkanes ( $\mathrm{n}-\mathrm{C}_{17}$ and $\mathrm{n}-\mathrm{C}_{18}$ ) relative to more recalcitrant branched isoprenoid alkanes (pristane and phytane) was observed at this site (St \#12): in fact, the ratios remained almost the same (Table 1). This could be a result of slow biodegradation associated with the introduction of these compounds at different rates.

It was also possible to ascertain, from Figure 8 , that the other places studied had similar or even lower hydrocarbon concentrations than they had before the oil spill. The results reported for Sts \#3, \#4, $\# 7$ and \#10 suggest that the spillage's impact, if any, did not persist at these locations. This hypothesis is confirmed by Figure 6, in which the plots related to these stations are close to or below the expected concentration curve. However, of no less importance is the fact that these stations are continuously receiving inputs from sewage outlets and harbor and port activities (CETESB, 1994b), which might be making a significant hydrocarbon contribution (LAW, 1981). The reference site, St \#16, was not affected by the oil spill, thus confirming that this site is free of any hydrocarbon contamination from the SSC. 


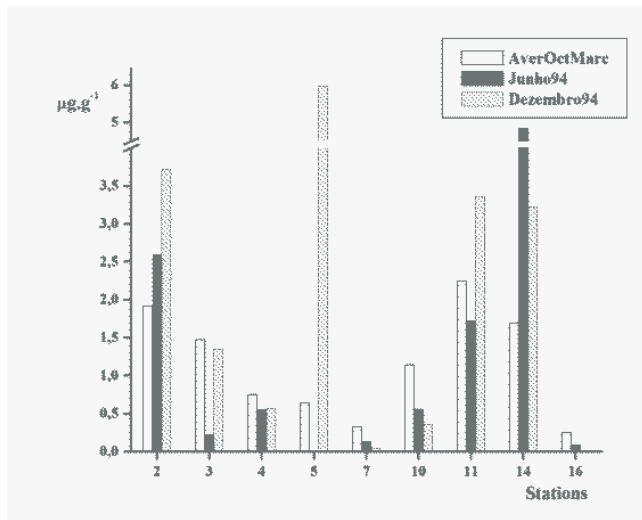

Fig. 8. Variation of total of n-alkane concentration $\left(\mathrm{mg} \mathrm{g}^{-1}\right)$ in sediments from São Sebastião Channel. Average concentration between Oct/93 and Mar/94 = $\square$; Jun/94 (one month after the oil spill $)=\boldsymbol{\square} ;$ Dec/94 $(7$ months after the

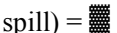

\section{Conclusions}

Hydrocarbon data from a monitoring program revealed that the sediments from the sites studied inside the São Sebastião Channel (SSC) show they are affected by human activity. Results revealed a great input from biogenic sources, mainly from terrestrial plants, in addition to petroleum hydrocarbons, in most of the samples analyzed, suggesting a mixture of pollutants from the various sources in the area. The total n-alkanes in sediments remained almost constant during the two first months studied, with relatively high hydrocarbon concentrations and marked petroleum characteristics in some areas, mainly in the north of the SSC. These contaminants were likely carried there by the northeasterly wind-driven currents which predominate in the channel, in addition to those contributed by some specific anthropic (nautical and port) activities undertaken close to the stations concerned, as well as sewage effluent.

The data from the monitoring program allowed us to observe changes in the hydrocarbon concentrations in sediments after the occurrence of the oil spill in May 1994 and to investigate the fate of the oil inside the channel. Some areas were clearly impacted by the oil, the site closest to of the pipeline rupture being the most affected. Seven months after the accident, these sediments were still highly contaminated. The oil spilt was driven mainly to the north of the SSC and the farthest stations, \# 2 and \# 14 , received more oil than did the others inside the channel. Seven months later, St \#14 showed signs of recovery and this could be attributed to its being a high-energy site. On the other hand, St \#2 did not present any signs of recovery. Further sedimentation studies needs to be conducted in the area so as better to understand this difference in degradation rate, since no other significant input was detected.

The data showed that the aliphatic hydrocarbon analyses were powerful tools for the evaluation of the fate of the oil spillage inside the SSC and the verification of recovery trends. The northern part of this channel is more susceptible to the effects of oil spills, mainly because of the influence of the predominant northeasterly wind-driven currents. This study showed, further, the importance of having baseline hydrocarbon concentration data which, in this case, permitted us to follow up the fate of an accidental oil input and distinguish the continuous hydrocarbon contribution from that due to an accident. On this basis, monitoring programs are strongly to be recommended in areas subject to oil accidents.

\section{ACKNOWLEDGEMENTS}

The authors gratefully acknowledge the support given to this project by FAPESP, CNPq and CETESB. We would like to thank the technicians of CETESB and the Oceanographic Institute of the University of São Paulo, for their help both in the field and the laboratory. Special thanks go to Dr. José Roberto B. Souza, for helping with the statistical analyses.

\section{REFERENCES}

BÍCEGO, M. C.; ZANARDI, E.; ITO, R. G.; WEBER, R. R. Hydrocarbons in surface sediments of Admiralty Bay, King George Island, Antarctica. Pesqui. Antart. Bras., v. 3, p. 15-21, 1998.

BÍCEGO, M. C.; ZANARDI-LAMARDO, E.; TANIGUCHI, S.; MARTINS, C. C.; SILVA, D. A. M.; SASAKI, S. T.; ALBERGARIA-BARBOSA, A. C. R.; PAOLO, F. S.; WEBER, R. R.; MONTONE, R. C. Results from a 15year study on hydrocarbon concentrations in water and sediment from Admiralty Bay, King George Island, Antarctica. Antarct. Sci., v. 21, n. 3, p. 209-220, 2009.

CASTRO, B. M.; MIRANDA, L. B.; SILVA, L. S.; FONTES, R. F. C.; PEREIRA, A. F.; COELHO, A. L. Processos físicos: hidrografia, circulação e transporte. In: PIRES-VANIN, A. M. S. (Ed.). Oceanografia de um ecossistema subtropical: plataforma de São Sebastião, SP. São Paulo: EDUSP, 2008. p. 59-121.

CETESB. Operação TEBAR V: relatório de atendimento. São Paulo: Cetesb, 1994a. 116p.

CETESB. Relatório de balneabilidade das praias paulistas. São Paulo: Cetesb, 1994b. 112p. (Série Relatórios).

CHRASTANSKY, A.; CALLIES, U. Model-based long-term reconstruction of weather-driven variations in chronic oil pollution along the German North Sea coast. Mar. Pollut. Bull., v. 58, n. 7, p. 967-975, 2009. 
CHRASTANSKY, A.; CALliES, U.; FleET, D. M. Estimation of the impact of prevailing weather conditions on the occurrence of oil-contaminated dead birds on the German North Sea coast. Environ. Pollut., v. 157, n. 1, p. 194-198, 2009.

CRIPPS, G. C.; SHEARS, J. The fate in the marine environment of a minor diesel fuel spill from an Antarctic Research Station. Environ. Monit. Assess., v. 46, n. 3, p. 221-232, 1997.

DE LA HUZ, R.; LASTRA, M.; JUNOY, J.; CASTELlANOS, C.; VIÉITEZ, J. M. Biological impacts of oil pollution and cleaning in the intertidal zone of exposed sandy beaches: preliminary study of the "Prestige" oil spill. Estuarine, Coastal Shelf Sci., v. 65, n. 1/2, p. 19-29, 2005.

GESAMP. The revised GESAMP hazard evaluation procedure for chemical substances carried by ships: reports and studies IMO/FAO/UNESCO/WMO/WHO/IAEA/UN/UNEP Joint Group of Experts on the Scientific Aspects of Marine Environmental Protection. London: IMO, 2002. 137 p. (GESAMP Reports and Studies, n. 64).

GUO, W. J.; WANG, Y. X.; XIE, M. X.; CUI, Y. J. Modeling oil spill trajectory in coastal waters based on fractional Brownian motion. Mar. Pollut. Bull., v. 58, n. 9, p. 1339-1346, 2009.

GOUGH, M. A.; ROWLAND, S. J. Characterization of unresolved complex-mixtures of hydrocarbons in petroleum. Nature, v. 344, n. 6267, p. 648-650, 1990.

HUMPHREY, B.; BOEHM, P. D.; HAMILTON, M. C.; NORSTROM, R. J. The fate of chemically dispersed and untreated crude oil in Arctic benthic biota. Arctic, v. 40, suppl. 1, p. 149-161, 1987.

LAW, R. J. Hydrocarbon concentrations in water and sediments from UK marine waters determined by fluorescence spectroscopy. Mar. Pollut. Bull., v. 12, n. 5, p. 153-157. 1981.

LEMOS, A. T.; SOARES, I. D.; GHISOLFI, R. D.; CIRANO, M. Oil spill modeling off the Brazilian eastern coast: the effect of tidal currents on oil fate. Rev. Bras. Geof., v. 27, n. 4, p. 625-639, 2009.

LEMKAU, K. L.; PEACOCK, E. E.; NELSON, R. K.; VENTURA, G. T.; KOVECSES, J. L.; REDDY, C. M. The M/V Cosco Busan spill: source identification and short-term fate. Mar. Pollut. Bull., v.60, n. 11, p. 2123 2129, 2010.

LOPES, C. F.; MILANELLI, J. C. C.; PROSPERI, V. A.; ZANARDI, E.; TRUZZI, A. C. Coastal Monitoring Program of São Sebastião channel: assessing the effects of 'Tebar V' oil spill on rocky shore populations. Mar. Pollut. Bull., v. 34, n. 11, p. 923-927, 1997.

MAIOLI, O. L. G.; RODRIGUES, K. C.; KNOPPERS, B. A.; AZEVEDO, D. A. Pollution source evaluation using petroleum and aliphatic hydrocarbons in surface sediments from two Brazilian estuarine systems. Org. Geochem., v. 41, n. 9, p. 966-970, 2010. [Advances in Organic Geochemistry 2009 - Proceedings of the 24th International Meeting on Organic Geochemistry].

MAYNARD, A. W. Environmental tests: are they valid? CHEMTECH, v. 20, p. 151-155, 1990.

MELVILLE, F.; ANDERSEN, L. E.; JOLLEY, D. F. The Gladstone (Australia) oil spill - impacts on intertidal areas: baseline and six months post-spill. Mar. Pollut. Bull., v. 58, n. 2, p. 263-271, 2009.
MORALES-CASELLES, C.; KALMAN, J.; RIBA, I.; DELVALLS, T. A. Comparing sediment quality in Spanish littoral areas affected by acute (Prestige, 2002) and chronic (Bay of Algeciras) oil spills. Environ. Pollut., v. 146, n. 1, p. 233-240, 2007.

MORALES-CASELLES, C.; RIBA, I.; SARASQUETE, C.; ANGEL DELVALLS, T. The application of a weight of evidence approach to compare the quality of coastal sediments affected by acute (Prestige 2002) and chronic (Bay of Algeciras) oil spills. Environ. Pollut., v. 156, n. 2, p. 394-402, 2008.

NRC (National Research Council). Oil in the sea III: inputs, fates and effects. Washington: National Academy Press, 2003. 280 p.

PENELA-ARENAZ, M.; BELLAS, J.; VÁZQUEZ, E. Chapter 5: effects of the Prestige oil spill on the biota of NW Spain: 5 years of learning. Adv. Mar. Biol., v. 56, p. 365-396, 2009.

PETERS, K. E.; WALTERS, C. C.; MOLDOWAN, J. M. The biomarker guide. $2^{\text {nd }}$. ed. Cambridge: Cambridge University Press,. 2005. 704p. [v. 2 biomarkers and isotopes in petroleum exploration and earth history].

POFFO, I. R. F.; NAKASAKI, A.; EYSINK, G. G. J. Dinâmica dos vazamentos de óleo no Canal de São Sebastião - São Paulo (1974-1994). São Paulo: Cetesb, 1996. 124p.

POFFO, I. R. F.; XAVIER, J. C. M.; SERPA, R. R. A história dos 27 anos de vazamento de óleo no litoral norte do estado de São Paulo (1974-2000). Rev. Meio Ambiente Ind., v. 30, p. 98-104, 2001.

QUEVAUVILLER, P. H.; COFINO, W.; VIJVERBERG, A.; WELLS, D. E.; GRIEPINK, B. Quality assurance in marine monitoring. In: QUEVAUVILLER, P., ed. Quality assurance in marine monitoring programmes: report and programme: proceedings of the workshop held in Noordwijkerhout. 21-23 de maio de 1990. [S.1.]: Commision of the European Communities, 1992. 43p. (Euratom publications - EUR, 14297).

READMAN, J. W.; PRESTON, M. R.; MANTOURA, R. F. C. An integrated technique to quantify sewage, oil and PAH pollution in estuarine and coastal environments. Mar. Pollut. Bull., v. 17, n. 7, p. 298-308, 1986.

SÁNCHEZ, F.; VELASCO, F.; CARTES, J. E.; OLASO, I.; PRECIADO, I.; FANELLI, E.; SERRANO, A.; GUTIERREZ-ZABALA, J. L. Monitoring the Prestige oil spill impacts on some key species of the Northern Iberian shelf. Mar. Pollut. Bull., v. 53, n. 5/7, p. 332349, 2006.

SNEADAKER, S. C.; GLYNN, P. W.; RUMBOLD, D. G.; CORCORAN, E. F. Distribution of $n$-alkanes in marine samples from Southeast Florida. Mar. Pollut. Bull., v. 30, p. 83-89, 1995

SOTILLO, M. G.; ALVAREZ FANJUL, E.; CASTANEDO, S.; ABASCAL, A. J.; MENENDEZ, J.; EMELIANOV, M.; OLIVELLA, R.; GARCÍA-LADONA, E.; RUIZVILLARREAL, M.; CONDE, J.; GÓMEZ, M.; CONDE, P.; GUTIERREZ, A. D.; MEDINA, R. Towards an operational system for oil-spill forecast over Spanish waters: initial developments and implementation test. Mar. Pollut. Bull., v. 56, n. 4, p. 686-703, 2008.

SUGUIO, K. Introdução a sedimentologia. São Paulo: Blücher: EDUSP, 1973. 317p. 
UNEP (UNITED NATIONS ENVIRONMENT PROGRAMME). Determination of petroleum hydrocarbons in sediments. Monaco: IOC: IAEA, 1992. 97p. (Reference methods for marine pollution studies; n. 20).

VOLKMAN, J. K.; HOLDSWOTH, D. G.; NEILL, G. P.; BAVOR Jr., H. J. Identification of natural, anthropogenic and petroleum hydrocarbons in aquatic sediments. Sci. Total Environ., v. 112, n. 2/3, p. 203219, 1992.

YIM, U. H.; HA, S. Y.; AN, J. G.; WON, J. H.; HAN, G. M.; HONG, S. H.; KIM, M.; JUNG, J. H.; SHIM, W. J. Fingerprint and weathering characteristics of stranded oils after the Hebei Spirit oil spill. J. Hazard. Mater., v. 197, p. 60-69, 2011.
ZANARDI, E.; BÍCEGO, M. C.; MIRANDA, L. B.; WEBER, R. R. Distribution and origin of hydrocarbons in water and sediment in São Sebastião, SP, Brazil. Mar. Pollut. Bull., v. 38, n. 4, p. 261-267, 1999a.

ZANARDI, E.; BÍCEGO, M. C.; WEBER, R. R. Dissolved/dispersed petroleum aromatic hydrocarbons in the São Sebastião Channel, São Paulo, Brazil. Mar. Pollut. Bull., v. 38, n. 5, p. 410-413, 1999b.

(Manuscript received 21 February 2011; revised 17 March 2013; accepted 14 April 2013) 